\title{
Dirofilaria repens transmission in southeastern Finland
}

\author{
Risto Pietikäinen ${ }^{1}$, Stig Nordling ${ }^{2}$, Sakari Jokiranta ${ }^{3}$, Seppo Saari ${ }^{4}$, Petra Heikkinen ${ }^{5}$, Chris Gardiner ${ }^{6}$, \\ Anne-Marie Kerttula7 ${ }^{7}$ Tiina Kantanen ${ }^{8}$, Anna Nikanorova ${ }^{9}$, Sauli Laaksonen ${ }^{4}$, Antti Lavikainen ${ }^{3}$ and \\ Antti Oksanen ${ }^{5^{*}}$ (D)
}

\begin{abstract}
Background: The spread of vector-borne diseases to new regions has become a global threat due to climate change, increasing traffic, and movement of people and animals. Dirofilaria repens, the canine subcutaneous filarioid nematode, has expanded its distribution range northward during the last decades. The northernmost European locations, where the parasite life-cycle has been confirmed, are Estonia and the Novgorod Region in Russia.

Results: Herein, we describe an autochthonous D. repens infection in a Finnish woman. We also present two cases of D. repens infection in imported dogs indicating the life-cycle in the Russian Vyborg and St Petersburg areas, close to the Finnish border.

Conclusions: The most obvious limiting factor of the northern distribution of $D$. repens is the summer temperature, due to the temperature-dependent development of larvae in vectors. With continuing climate change, further spread of $D$. repens in Fennoscandia can be expected.
\end{abstract}

Keywords: Vector-borne nematodes, Autochthonous infection, Climate change, Zoonosis, Dirofilariosis

\section{Background}

Species of Dirofilaria (Spirurida, Onchocercidae) are vector-borne filarioid nematode parasites. Worldwide, filarioid nematodoses with major public health importance include lymphatic filariosis and onchocercosis, while dirofilariosis, setariosis and onchocercosis cause major animal health hazards and have economic implications [1]. Animal parasitic filarioids are often also zoonotic. There is recent evidence documenting the expansion of some animal diseases associated with filarioid parasites to boreal and sub-Arctic areas, including Finland [2, 3], and at northern latitudes, species of several filarioid genera are now known to be emerging $[4,5]$.

Dirofilaria immitis, the dog heartworm, and Dirofilaria repens, the canine subcutaneous worm, use mosquitoes as vectors. The host specificity of these parasites is not high and they are found occasionally in foxes and cats as well as sporadically in other mammal species, including

\footnotetext{
* Correspondence: antti.oksanen@evira.fi

${ }^{5}$ Finnish Food Safety Authority Evira, Wildlife and aquatic pathology (FINPAR), Elektroniikkatie 3, 90590 Oulu, Finland

Full list of author information is available at the end of the article
}

humans [6, 7]. Since potential mosquito vectors are available virtually over all the sub-Arctic, and many arctic regions, the northern border of distribution of these Dirofilaria species is not determined by the availability of the vectors but rather by the ability of microfilariae to mature into infectious larvae in the mosquito vector [8-10], as maturation is temperature-dependent. Dirofilaria repens development in mosquitoes to the infective stage takes $8-13$ days at $28-30{ }^{\circ} \mathrm{C}, 10$ 11 days at $26{ }^{\circ} \mathrm{C}$ and $16-20$ days at $22{ }^{\circ} \mathrm{C}$ [11]. At temperatures below $14{ }^{\circ} \mathrm{C}, \mathrm{D}$. immitis larval development ceases [12], but restarts if the temperature rises. When a mosquito with infective stage (L3) larvae feeds on a human being, it may infect this aberrant host [13]. Both subcutaneous, periorbital and eyelid human infections caused by $D$. repens occur in endemic areas [14].

Dirofilaria repens is endemic in dogs in Africa, southeastern Asia, and the Mediterranean region [15]. In Europe, its distribution range has recently expanded northward, assumedly partly due to climate change $[8,16-18]$. In a 2012 publication, the European Scientific Counsel 
Companion Animal Parasites [19] reported the parasite to have established in Austria, Germany and Poland. It has also been found in Lithuania in dogs [20], and in Latvia, in both dogs and humans $[21,22]$. Thus far, the northernmost European site where the parasite life-cycle has been confirmed to take place is Estonia, where $D$. repens microfilaraemia was seen in three dogs in 2013-2014 [23]. In European Russia, the reported northern limit of D. repens is in the Novgorod Region [24]. According to Russian veterinary practitioners, however, dirofilariosis occurs in the dog population of Saint Petersburg, as was also reported on a veterinary clinic website (Anna Nikanorova, pers. comm. 2017). The Novgorod Region and the southern part of the Leningrad Region are located approximately at the same latitude as Estonia (Fig. 1). Recently, three cases of human ocular dirofilariosis were reported from Saint Petersburg $[25,26]$. In one case, the patient had reportedly not left the region during the previous three years, suggesting endemicity of $D$. repens in the Leningrad Region. In addition, a single case of dirofilariosis was reported in 1999 in the city of Arkhangelsk [27]. A 15 year-old child was suspected to have been infected in Arkhangelsk, but because of travel history to Sochi and Rostov-on-Don, the origin of infection could not be confirmed. In Yakutsk, Siberia, located over permafrost and known as the coldest city on earth, three $D$. repens infections were reported in dogs and one in a cat [28]. Moreover, six cases of $D$. immitis infection were diagnosed in dogs and one in a fox between 1996 and 2010 [28].

In Finland, autochthonous $D$. repens cases in dogs have not been diagnosed previously, but a dog imported from Romania was found infected in 2014 [29]. Another species, Dirofilaria ursi, a parasite of the brown bear, using black flies as vectors and having lower temperature requirements for development in its vector [30], is prevalent in Finnish bears at least in Northern Karelia (unpublished pers. obs.).

Human dirofilariosis has been increasingly reported in the past few years and thus should be considered an emerging zoonosis in many parts of the world [13, 31, 32]. Here, we report in a human being the first autochthonous $D$. repens infection in Finland. The infected patient lived in Hamina, southeastern Finland (Fig. 1), which is around $35 \mathrm{~km}$ from the Russian border. We document the surgical removal of the parasite nodule and the identification of the adult, gravid female nematode and its microfilariae. Further, we discuss possible transmission pathways. Moreover, we report two cases in dogs imported to Finland from St Petersburg and Vyborg, Russia, the latter just $25 \mathrm{~km}$ from the Finnish border and $90 \mathrm{~km}$ from Hamina.

\section{Autochthonous human case, southeastern Finland}

In March 2015, a 70-year-old Finnish woman, with no recent travel history abroad, sought medical care due to erythema, swelling and some itching on the volar side of her left forearm. Suspecting an allergic reaction, the general practitioner prescribed a single dose of oral corticosteroid and a course of antihistamine. After four days, antibacterial cephalexin chemotherapy was initiated because the symptoms had not abated and painful nodules were observed in the forearm. The absolute leucocyte count $\left(13.1 \times 10^{9} / \mathrm{l}\right.$; norm $\left.3.4-8.2 \times 10^{9} / \mathrm{l}\right)$, eosinophil leukocyte count $\left(1.2 \times 10^{9} / \mathrm{l}\right.$; norm $\left.0.03-0.1 \times 10^{9} / \mathrm{l}\right)$ and C-reactive protein concentration $(22 \mathrm{mg} / \mathrm{l}$; norm $<3 \mathrm{mg} /$ l) were elevated. Soon after starting cephalexin, the patient got a possible allergic reaction, with flush over the face and upper chest, and the antibiotic was replaced with piperacillin and tazobactam for three days and,

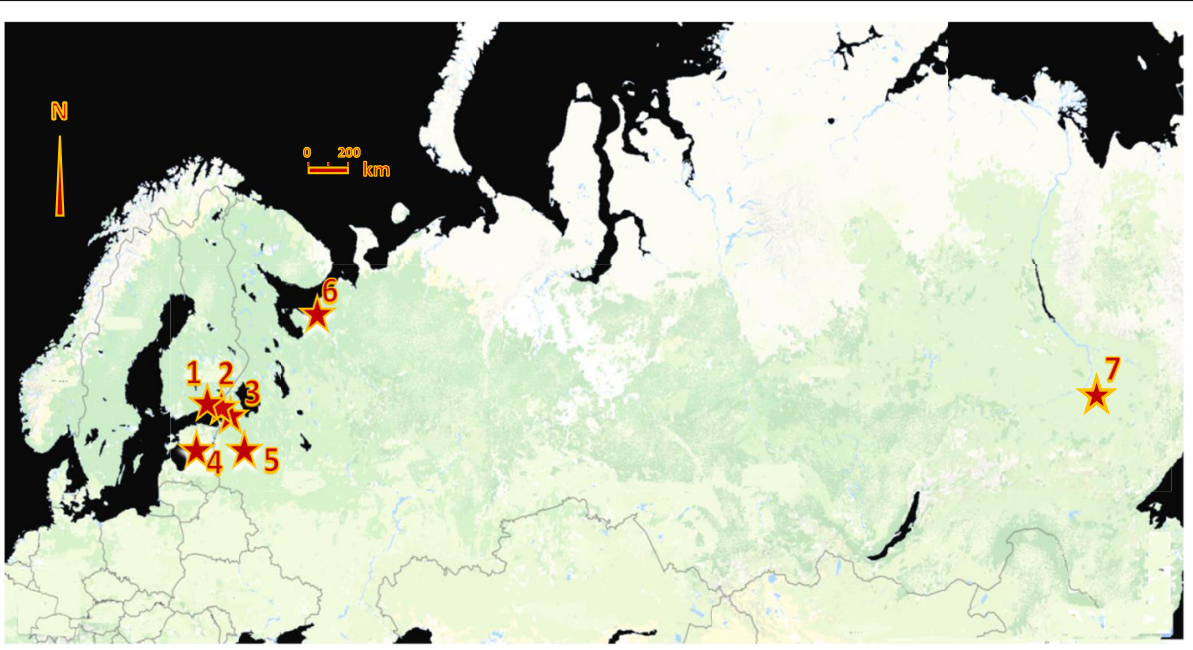

Fig. 1 The northernmost Dirofilaria repens infections found reported. See text for further information of the reports. 1, Hamina $\left(61^{\circ} \mathrm{N}, 27^{\circ} \mathrm{E}\right) ; 2$, Vyborg $\left(61^{\circ} \mathrm{N}, 20^{\circ} \mathrm{E}\right) ; 3$, St Petersburg $\left(60^{\circ} \mathrm{N}, 30^{\circ} \mathrm{E}\right) ; 4$, Tartu $\left(58^{\circ} \mathrm{N}, 27^{\circ} \mathrm{E}\right) ; 5$, Novgorod Oblast $\left(58^{\circ} \mathrm{N}, 33^{\circ} \mathrm{E}\right) ; 6$, Arkhangelsk $\left(65^{\circ} \mathrm{N}, 41^{\circ} \mathrm{E}\right) ; 7$, Yakutsk $^{\circ}$ $\left(62^{\circ} \mathrm{N}, 130^{\circ} \mathrm{E}\right)$ 
after that, continued with clindamycin. Over the next two weeks, the pain and swelling disappeared, but a thumb tip size nodule remained in the forearm. In early April, 20 days after the first visit to the general practitioner, the nodule was surgically removed for histological examination. The excision wound healed normally leaving only a minor scar.

Upon histological study, an inflammatory reaction composed of eosinophilic granulocytes and histiocytes surrounding a nematode was noted. Morphology revealed at least one gravid, adult female filarioid nematode, having a cuticle with evenly spaced external longitudinal cuticular ridges. The musculature was coelomyarian (muscle fibers in a cylindrical pattern) and polymyarian (many cells in each quadrant of a crosssection), and the intestine was very small (Fig. 2). The nematode had two large uteri filled with microfilariae. These findings were characteristic of Dirofilaria spp. The external longitudinal cuticular ridges ruled out $D$. immitis, but we could not distinguish between other potential species. Since D. repens is present in Estonia, and the brown bear parasite $D$. ursi is prevalent in eastern Finland, we aimed at specific diagnosis by both morphological examination of microfilariae and molecular identification.

Three weeks after the parasitic nodule had been excised, diurnal and nocturnal whole heparine blood samples were collected for microscopic analysis of possible microfilariae, concentrated using a standard filtration method with Millipore filters [33], and stained on microscope slides with Giemsa. In the nocturnal samples, microfilariae were detected with a maximum of $2 \mathrm{mf} / \mathrm{ml}$. Two months after the excision, $1 \mathrm{mf} / 8 \mathrm{ml}$ was still detected, and in August, 4.5 months after the excision, no microfilariae were found from the patient.

The microfilariae possessed 2 or 3 nuclei in the cephalic space (Fig. 2). The length of 10 microfilariae was measured, which was not easy since caudal filaments of

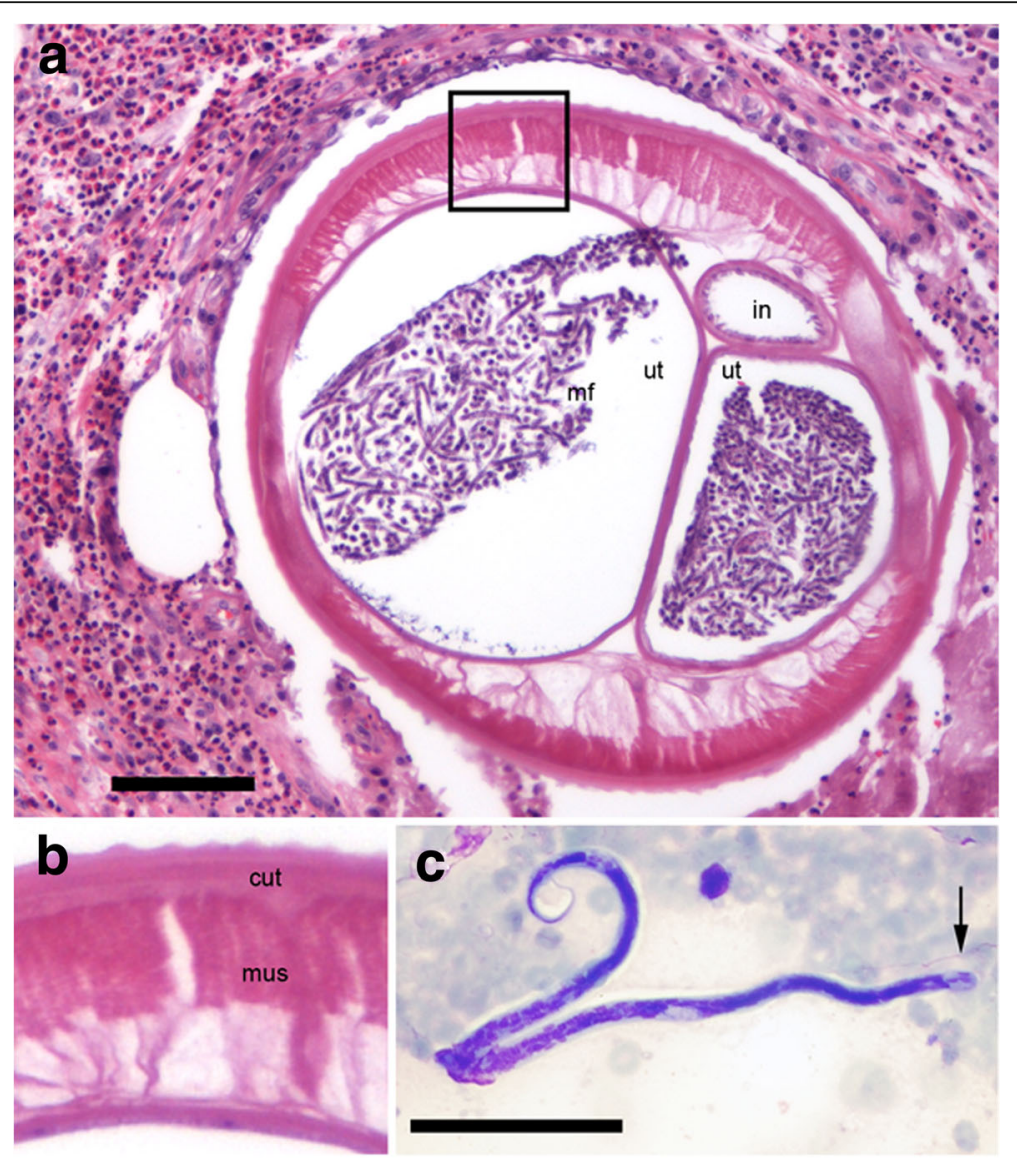

Fig. 2 Histopathology as seen in the subcutaneous lesion ( $\mathbf{a}$ and $\mathbf{b}$ ) and microfilaria found in the blood smear (c) from the human patient, a 70 year-old female. A diffuse dermal inflammatory infiltrate composed of eosinophilic granulocytes and histiocytes surrounding an adult female filarioid nematode can be observed in (a). The area in the rectangle is enlarged in (b). A cuticle with evenly spaced external longitudinal cuticular ridges, a musculature of coelomyarian type, a small intestine and a paired uterus filled with microfilariae were considered typical of Dirofilaria spp. Haematoxylin-eosin stained histological section. A microfilaria possessing three nuclei in a large cephalic space (arrow) can be observed in (c). Abbreviations:

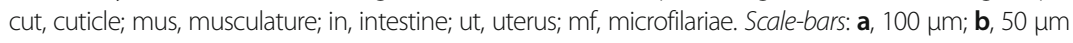


crooked microfilariae were not clearly visible (Fig. 2). Length measurements, $200-260 \mu \mathrm{m}$, agreed with that reported for $D$. ursi in bears $(198-242 \mu \mathrm{m})$ [34]. Microfilariae of $D$. repens in dogs have been reported to be longer $(323 \pm 21 \mu \mathrm{m})$ [35], or, using a somewhat different Knott's method, even longer $(369 \pm 11 \mu \mathrm{m})$ [36].

\section{Infection in two dogs imported from Vyborg and St Petersburg}

We also report here two confirmed cases in dogs imported to Finland from Russia, one from Vyborg and another from St Petersburg, located about $25 \mathrm{~km}$ and $160 \mathrm{~km}$ from the Finnish border, respectively.

In May 2013, a 2 year-old Rabbit Dachshund, imported from St Petersburg, Russia, more than a year earlier, was brought to a veterinary clinic in Turku with vomiting and presenting signs of abdominal pain. Laboratory examinations revealed, apparently unrelated to the presented illness, many $\mathrm{mf}$ in a Giemsa-stained thin blood film. Microfilariae were about $370 \mu \mathrm{m}$ in length, possessed rather short cephalic space terminating by a pair of nuclei separate from the remaining somatic nuclei of the microfilaria. These morphological features were considered typical of $D$. repens.

In 2015, a 15 month-old mixed breed bitch imported from Vyborg was presented for a routine ovariohysterectomy in Helsinki. During the surgery, the veterinary surgeon found a wormlike organism about $2 \mathrm{~cm}$ long squirming in the abdominal cavity. The surgeon preserved the worm in alcohol and sent it for identification. Based on anamnestic information, D. repens was suspected, but as the sample represented an immature nematode lacking diagnostic morphological features, the specimen was submitted for molecular identification.

\section{Molecular identification}

For a specific diagnosis, DNA was isolated from a blood sample containing $\mathrm{mf}$ from the human patient and from the ethanol-preserved worm specimen from the second canine case. DNA of three adult D. ursi specimens, from three different brown bears from eastern Finland, was used as a reference. Partial mitochondrial sequences of the cytochrome $c$ oxidase subunit 1 ( $\operatorname{cox} 1)$ gene and $12 S$ ribosomal DNA (rDNA) were amplified using previously reported filarioid-specific primers [37, 38]. Standard Sanger sequencing of the amplicons confirmed the causative agent to be $D$. repens in both the human and canine cases. The sequences (cox1, 649 bp; $12 S$ rDNA, $468 \mathrm{bp}$ ) of the human patient were identical with several published sequences of D. repens in GenBank (e.g. cox1, Estonian canine isolate, accession no. KR780980; $12 \mathrm{~S}$ rDNA, Russian human isolate, KM205372). The cox1 sequence of the canine specimen and that of the human patient were identical, and the identity in $12 \mathrm{~S} \mathrm{rDNA}$ was
99\%. In both sequence regions of the human and canine specimens, the identity to $D$. ursi was $92 \%$. The sequence data are available in the GenBank database under the accession numbers KY828978-KY828986.

\section{Discussion}

The patient was a resident of the town of Hamina, on the southern coast of Finland and about $35 \mathrm{~km}$ from the Russian border, living in a suburban environment. She said she had stayed within Finnish territory since her last visit to Tallinn, Estonia, four years prior. As D. repens has been reported to cause symptoms to humans within one year of infection [13], it is probable that she got infected in the summer of 2014, which she spent mostly in Hamina and at a location approximately $50 \mathrm{~km}$ from Hamina (35 km from Russian border). She practiced outdoor activities, such as collecting forest berries and mushrooms and hiking in the forest. Mosquitoes were abundant in these environments.

We identified the nematode from the patient's subcutaneous tissue and its $\mathrm{mf}$ in the circulating blood morphologically as a species of Dirofilaria, and the molecular methods unequivocally showed the worm to be $D$. repens. If we had based the diagnosis on $\mathrm{mf}$ morphology alone, possibly we would have misidentified those as microfilariae of $D$. ursi. The dwarfism of microfilariae, $\sim 20-40 \%$ shorter than those described from dogs [35], might indicate weakness and non-viability; the patient might have been a dead end host for the parasite with no transmission of infection possible further from her. Genchi et al. [11] state that, usually, D. repens parasites do not mature to adults in humans, but knew of three microfilaremic humans in Europe and one in Iran. Later, an Indian case was also reported [39].

The mean summer temperature at Kotka meteorological station (25 km from Hamina) in summer 2014 was $16.8{ }^{\circ} \mathrm{C}$, which is $0.7^{\circ} \mathrm{C}$ warmer than the mean summer temperature in 1980-2010 (http://ilmatieteenlaitos.fi/tilastoja-vuodesta-1961). Warm summers are known to promote the emergence of outbreaks of filarioid nematodes in arctic ungulates $[4,40]$. It appears that the conditions in summer 2014 may have been more favourable than average, enabling the development of $D$. repens to L3 larvae in mosquito vectors. The origin of $D$. repens in a mosquito in Hamina region is unknown, but two alternative hypothetical options are present. First, the nematode life-cycle might have established in the region perhaps years earlier. However, Finnish Food Safety Authority Evira annually collects hundreds of red foxes and raccoon dogs from southeastern Finland for other disease surveillance (especially rabies antibody and Echinococcus multilocularis), and has never identified $D$. repens in them (unpublished pers. obs.). Yet, the surveillance is not specifically aimed at $D$. repens, and its 
prevalence in foxes and raccoon dogs, somewhat aberrant hosts even in an endemic area, would not be expected to be high [6].

The other possibility is that the patient was infected by a mosquito which had carried the infection to Hamina from abroad. For example, it is possible that strong air currents might have blown mosquitoes from the Baltic States over the Gulf of Finland in summer 2014. Aedes punctor mosquitoes have been reported to be able to fly at least $46 \mathrm{~km}$ in still air and some evidence exists that on long flights mosquitoes take advantage of wind [41]. However, most mosquito species appear to have an average flight range of between just $25 \mathrm{~m}$ and $6 \mathrm{~km} \mathrm{[42].}$

The final transport of infected mosquitoes could also have been by cargo ship to the Port of Hamina, a major ship terminal in Finland. Passive transportation by vehicles is regarded to be the most important mode of Aedes albopictus long-distance dispersal within Europe [43].

The finding of $D$. repens in dogs imported from $\mathrm{Vy}-$ borg and St Petersburg indicates that the parasite has gained a foothold in close proximity of the Finnish border in the Karelian Isthmus. Thus, spreading from there and settling in southeastern Finland would be the simplest explanation. In Finland, heartworm preventive treatment of dogs is not common practice.

Although D. immitis is still regarded as a southern species in Europe, mostly restricted to the Mediterranean region [19], in Yakutsk, both $D$. repens and $D$. immitis thrive in spite of extremely cold winters. During the winter, the worms have homoeothermic conditions within the canine host. During the summers, when transmission potentially occurs, Yakutsk is warm (19611990 mean in July $18.7{ }^{\circ} \mathrm{C}$, https://www.yr.no/place/ Russia/Sakha/Yakutsk/statistics.html). Therefore, the 130 Dirofilaria Development Units (DDUs) (degree-days above $14{ }^{\circ} \mathrm{C}$ ) proposed to be required for development into the infective stage in mosquitoes $[8,11]$ can probably be reached within the mosquito lifespan during the summer; thus the low winter temperature is irrelevant.

\section{Conclusions}

It is evident that the patient reported here became infected by $D$. repens within the Finnish territory. Consideration of all the vector dispersal mechanisms, combined with climate change assessments, suggests that further expansion of $D$. repens in Finland, and perhaps other northern countries, is possible. In addition, it is probable that almost any filarioid nematodes parasitizing animals can, under appropriate circumstances, infect humans and undergo some degree of development [44, 45]. This topic is also highly timely, since the predicted change in temperature indicates a particularly strong warming trend at the high latitudes in the northern hemisphere, which may increase the incidence of climate-sensitive arthropodborne diseases such as filarioses (see [4, 35, 46, 47]). The parasites should be taken into account in human and animal disease diagnostics and in vector monitoring.

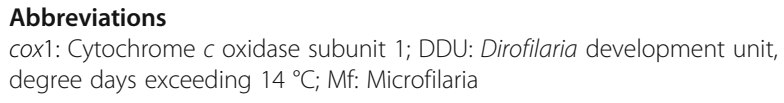

\section{Acknowledgements}

This work was done under the auspices of EurNegVec COST Action TD1303. We thank the veterinary clinics in Turku (DVM Johanna Koponen, KoiraKissaklinikka) and Helsinki (DVM Päivi Kuisma, Evidensia) for the dog parasites. We thank Kymenlaakso Central Hospital for covering the manuscript processing charges. Finally, we thank Anu Kantele for constructive criticism on the manuscript.

\section{Funding}

Dr Pietikäinen received funding from Kymenlaakso Central Hospital to cover manuscript processing charges.

\section{Availability of data and materials}

The sequences are available in the GenBank database under the accession numbers KY828978-KY828986.

\section{Authors' contributions}

RP, SN, SJ and TK identified the human infection to be caused by a filarioid nematode. SJ, AL, AO and CG identified the nematode as a Dirofilaria species. AL, AMK and PH identified the species of both human and canine parasites as $D$. repens by molecular methods. SS described the canine cases. $A L$ and SS described the microfilariae. AL, SS, AN, SL and AO summarized the epidemiology of $D$. repens in the north, AN concentrated in Russia. All authors participated in drafting the manuscript. All authors read and approved the final manuscript.

\section{Ethics approval and consent to participate}

Not applicable.

\section{Consent for publication \\ Not applicable.}

\section{Competing interests}

The authors declare that they have no competing interests.

\section{Publisher's Note}

Springer Nature remains neutral with regard to jurisdictional claims in published maps and institutional affiliations.

\section{Author details}

${ }^{1}$ Kymenlaakso Central Hospital, Kotkantie 41, 48210 Kotka, Finland. ${ }^{2}$ Faculty of Medicine, Department of Pathology, University of Helsinki, P.O. Box 21, 00014 University of Helsinki, Helsinki, Finland. ${ }^{3}$ Department of Microbiology and Immunology, University of Helsinki, P.O. Box 21, 00014 University of Helsinki, Helsinki, Finland. ${ }^{4}$ Faculty of Veterinary Medicine, Department of Veterinary Biosciences, University of Helsinki, P.O. Box 66, 00014 University of Helsinki, Helsinki, Finland. ${ }^{5}$ Finnish Food Safety Authority Evira, Wildlife and aquatic pathology (FINPAR), Elektroniikkatie 3, 90590 Oulu, Finland. ${ }^{6}$ Veterinary Pathology Services, Joint Pathology Center, 606 Stephen Sitter Ave. Silver Spring, Silver Spring, MD 20910-1290, USA. ${ }^{7}$ HUSLAB, Division of Clinical Microbiology, P.O. Box 720, 00029 HUS, Helsinki, Finland. ${ }^{8} \mathrm{HUSLAB}$, Division of Pathology, P.O. Box 720, 00029 HUS, Helsinki, Finland. ${ }^{9}$ The Moscow State Academy of Veterinary Medicine and Biotechnology named after KI Skryabin, Akademika Skryabina Street, 23 Moscow, Russia.

Received: 10 July 2017 Accepted: 25 October 2017

Published online: 10 November 2017

\section{References}

1. World Health Organization. Wkly Epidemiol Rec. 2007;82:361-80.

2. Laaksonen S, Kuusela J, Nikander S, Nylund M, Oksanen A. Outbreak of parasitic peritonitis in reindeer in Finland. Vet Rec. 2007;160:835-41. 
3. Laaksonen S, Solismaa M, Kortet R, Kuusela J, Oksanen A. Vectors and transmission dynamics for Setaria tundra (Filarioidea; Onchocercidae), a parasite of reindeer in Finland. Parasit Vectors. 2009;2:3.

4. Laaksonen S, Oksanen A, Kutz S, Jokelainen P, Holma-Suutari A, Hoberg E. Filarioid nematodes, threat to arctic food safety and security - bioinvasion of vector-borne filarioid nematodes in the arctic and boreal ecosystems. In: Paulsen P, Bauer A, Smulders FJM, editors. Game meat hygiene: food safety and security. Wageningen, the Netherlands: Wageningen Academic Publishers; 2017. p. 101-20

5. Solismaa M, Laaksonen S, Nylund M, Pitkänen E, Airakorpi R, Oksanen A. Filarioid nematodes in cattle, sheep and horses in Finland. Acta Vet Scand. 2008:50:20.

6. Ionică AM, Matei IA, D'Amico G, Ababii J, Daskalaki AA, Sándor AD, et al. Filarioid infections in wild carnivores: a multispecies survey in Romania. Parasit. Vectors. 2017;10:332.

7. Manfredi MT, DiCerbo A, Genchi M. Biology of filarial worms parasitizing dogs and cats. Mappe Parassitologiche. 2007:8:40-5.

8. Genchi C, Mortarino M, Rinaldi L, Cringoli G, Traldi G, Genchi M. Changing climate and changing vector-borne disease distribution: the example of Dirofilaria in Europe. Vet Parasitol. 2011;176:295-9.

9. Sassnau R, Genchi C. Qualitative risk assessment for the endemisation of Dirofilaria repens in the state of Brandenburg (Germany) based on temperature-dependent vector competence. Parasitol Res. 2013;112:2647-52.

10. Deplazes P, Eckert J, Mathis A, von Samson-Himmelstjerna G, Zahner H. Parasitology in veterinary medicine. Wageningen, the Netherlands: Wageningen Academic Publishers; 2016.

11. Genchi C, Rinaldi L, Mortarino M, Genchi M, Cringoli G. Climate and Dirofilaria infection in Europe. Vet Parasitol. 2009;163:286-92.

12. Ledesma N, Harrington L. Fine-scale temperature fluctuation and modulation of Dirofilaria immitis larval development in Aedes aegypti. Vet Parasitol. 2015;209:93-100.

13. Pampiglione S, Rivasi F. Human dirofilariasis due to Dirofilaria (Nochtiella) repens: an update of world literature from 1995 to 2000. Parassitologia. 2000;42:231-54

14. Simón F, Siles-Lucas M, Morchón R, González-Miguel J, Mellado I, Carretón E, Montoya-Alonso JA. Human and animal dirofilariasis: the emergence of a zoonotic mosaic. Clin Microbiol Rev. 2012;25:507-44.

15. Soulsby EJL. Helminths, arthropods and protozoa of domesticated animals. 7th ed. London: Bailliere Tindall; 1982.

16. Sassnau R, Czajka C, Kronefeld M, Werner D, Genchi C, Tannich E, et al. Dirofilaria repens and Dirofilaria immitis DNA findings in mosquitoes in Germany: temperature data allow autochthonous extrinsic development. Parasitol Res. 2014;113:3057-61.

17. Matějů J, Chanová M, Modrý D, Mitková B, Hrazdilová K, Žampachová V, et al. Dirofilaria repens: emergence of autochthonous human infections in the Czech Republic (case reports). BMC Infect Dis. 2016;16:171.

18. Fuehrer HP, Auer H, Leschnik M, Silbermayr K, Duscher G, Joachim A Dirofilaria in humans, dogs, and vectors in Austria (1978-2014) - from imported pathogens to the endemicity of Dirofilaria repens. PLoS Negl Trop Dis. 2016;10(5):e0004547

19. ESCCAP. Control of vector-borne diseases in dogs and cats. ESCCAP Guideline 5. 2nd ed. Published in October 2012. http://www.esccap.org/ uploads/docs/ih38c2d6 ESCCAP Guidelines GL5 010ct2012.pdf.

20. Jankauskaitè A, Pockevičius A, Petkevičius S. Roundworms in dogs subcutaneous tissue in Lithuania - The first case. Vet Info. 2011;79(5):30-1. (In Lithuanian).

21. Stepanjana L, Cirule D, Kirjusina M. Occurence of Dirofilaria spp. in dogs in Latvia (2008-2011). Proceedings of conference on "Current events in veterinary research and practice", Jelgava, Latvia, November 2012. 2012;2223(2012): 148-52

22. Melbarde-Gorkusa I, Abolins A, Strumfa I, Martinsons A, Gardovskis J. Human dirofilariasis in Latvia - the first case in surgical practice. Acta Chirurgica Latviensis. 2011;11:172-4

23. Jokelainen P, Mõtsküla PF, Heikkinen P, Ülevaino E, Oksanen A, Lassen B. Dirofilaria repens microfilaremia in three dogs in Estonia. Vector Borne Zoonotic Dis. 2016:16:136-8.

24. Ermakova LA, Nagorny SA, Krivorotova EY, Pshenichnaya NY, Matina ON. Dirofilaria repens in the Russian Federation: current epidemiology, diagnosis, and treatment from a federal reference center perspective. Int J Infect Dis. 2014:23:47-52
25. Barashkova SV. Case of dirofilariasis in adolescent in Saint-Petersburg: clinical and morphological characteristics. Žurnal Infektologii (Journal Infectology). 2011;3(3):108-10. (In Russian)

26. Zumbulidze NG, Kasimov FO, Yarovoy DA, Gavrilova EP. Ocular dirofilariasis: two case reports. Ophthalm J. 2016;9(1):83-9. (In Russian).

27. Nazarenko MY. [Clinical case of domestic dirofilariasis in child.] J Human Ecol. 2000;2:133-134 (In Russian).

28. Kolesova GG, Reshetnikov AD, Sleptsov ES, Barashkova Al. Dirofilariosis of carnivorous in Yakutia, the method of isolation filarial larvae from the blood of dogs. Russian J Parasitologists. 2013;(3):87-91. (In Russian).

29. Evira, Finnish Food Safety Authority. [New parasitic infection in a dog imported to Finland.] 2014. https://www.evira.fi/elaimet/elainten-terveys-jaelaintaudit/elaintaudit/lemmikkielaimet/koirat/koirien-maahantuontiinliittyvat-riskit/dirofilaria-repens/. (In Finnish).

30. Addison EM. Transmission of Dirofilaria ursi Yamaguti, 1941 (Nematoda: Onchocercidae) of black bears (Ursus americanus) by blackflies (Simuliidae). Can J Zool. 1980:58:1913-22

31. Pampiglione S, Canestri Trotti G, Rivasi F. Human dirofilariasis due to Dirofilaria(Nochtiella)repens: a review of world literature. Parassitologia. 1995; 37:149-93.

32. Pampiglione S, Rivasi F, Angeli G, Boldorini R, Incensati RM, Pastormerlo M, et al. Dirofilariasis due to Dirofilaria repens in Italy, an emergent zoonosis: report of 60 new cases. Histopathology. 2001;38:344-54.

33. World Health Organization. Bench aid for the diagnosis of filarial infections. Geneva: WHO; 1997

34. Michalski ML, Bain O, Fischer K, Fischer PU, Kumar S, Foster JM. Identification and phylogenetic analysis of Dirofilaria ursi (Nematoda: Filarioidea) from Wisconsin black bears (Ursus americanus) and its Wolbachia endosymbiont. J Parasitol. 2010;96:412-9.

35. Liotta JL, Sandhu GK, Rishniw M, Bowman DD. Differentiation of the microfilariae of Dirofilaria immitis and Dirofilaria repens in stained blood films. J Parasitol. 2013;99:421-5.

36. Magnis J, Lorentz S, Guardone L, Grimm F, Magi M, Naucke TJ, Deplazes P. Morphometric analyses of canine blood microfilariae isolated by the Knott's test enables Dirofilaria immitis and D. repens species-specific and Acanthocheilonema (syn. Dipetalonema) genus-specific diagnosis. Parasit Vectors. 2013:6:48.

37. Casiraghi M, Anderson TJ, Bandi C, Bazzocchi C, Genchi CA. Phylogenetic analysis of filarial nematodes: comparison with the phylogeny of Wolbachia endosymbionts. Parasitology. 2001;122:93-103.

38. Casiraghi M, Bain O, Guerrero R, Martin C, Pocacqua V, Gardner SL, et al. Mapping the presence of Wolbachia pipientis on the phylogeny of filarial nematodes: evidence for symbiont loss during evolution. Int J Parasitol. 2000;34:191-203.

39. Damle AS, Iravane Bajaj JA, Khaparkhuntikar MN, Maher GT, Patil RV. Microfilaria in human subcutaneous dirofilariasis: a case report. J Clin Diagn Res. 2014:8:113-4.

40. Laaksonen S, Pusenius J, Kumpula J, Venäläinen A, Kortet R, Oksanen A, et al. Climate change promotes the emergence of serious disease outbreaks of filarioid nematodes. EcoHealth. 2010;7:7-13.

41. Hocking $B$. The intrinsic range and speed of flight of insects. Trans R Ent Soc Lond. 1953;104:223-345.

42. Verdonschot PFM, Besse-Lototskaya AA. Flight distance of mosquitoes (Culicidae): a metadata analysis to support the management of barrier zones around rewetted and newly constructed wetlands. Limnologica. 2014 45:69-79.

43. Medlock J, Hansford KM, Schaffner F, Versteirt V, Hendrickx G, Zeller H, et al. A review of the invasive mosquitoes in Europe: ecology, public health risks, and control options. Vector-borne zoon. Dis. 2012:12:435-47.

44. Orihel TC, Eberhard ML. Zoonotic filariasis. Clin Microbiol Rev. 1998;11:366-81.

45. Innes JRM, Shoho C. Cerebrospinal nematodiasis. Focal encephalomyelomalacia of animals caused by nematodes (Setaria digitata): a disease which may occur in man. Arch Neurol Physch. 1953;70:325-49.

46. Patz JA, Epstein PR, Burke TA, Balbus JM. Global climate change and emerging infectious diseases. JAMA. 1996;275:217-23.

47. Kutz SJ, Hoberg EP, Nagy J, Polley L, Elkin B. "Emerging" parasitic infections in arctic ungulates. Integr Comp Biol. 2004:44:109-18. 